\title{
Cacao Diseases: Important Threats to Chocolate Production Worldwide
}

\author{
Presented at the Annual Meeting of The American Phytopathological Society \\ Joint with The Canadian Phytopathological Society and the Mycological Society of America, \\ July 30, 2006, Québec City, Québec, Canada
}

\section{Cacao Diseases: Important Threats to Chocolate Production Worldwide}

\author{
Randy C. Ploetz \\ University of Florida, IFAS, Department of Plant Pathology, Tropical Research \& Education Center, 18905 SW 280 th Street, Homestead, FL \\ 33031-3314.
}

\begin{abstract}
Ploetz, R. C. 2007. Cacao diseases: Important threats to chocolate production worldwide. Phytopathology 97:1634-1639.

Theobroma cacao, cacao, is an ancient, neotropical domesticate. It is now grown throughout the humid, lowland tropics and is the basis of a multibillion dollar confectionary trade. Diverse diseases impact production of the crop. They reduce yields by ca. $20 \%$, but could cause far greater losses if certain highly damaging diseases were to become more widely distributed. Among the most potentially dangerous of these diseases are frosty pod, caused by Moniliophthora roreri, and witches' broom, caused by $M$. perniciosa (previously Crinipellis perniciosa). These two diseases occur only in the Western Hemisphere, and severe
\end{abstract}

ABSTRACT losses would follow their introduction to West Africa and Asia, where ca. $86 \%$ of all cacao production occurs. Elsewhere, Cacao swollen shoot virus and the damaging black pod agent, Phytophthora megakarya, are found in Western Africa; whereas vascular streak dieback, caused by Oncobasidium theobromae, is present only in Asia. Breeding programs are challenged by minimal resistance to some of the diseases. Progress that has been made is threatened by the "emergence" of other serious diseases, such as Ceratocystis wilt (Ceratocystis cacaofunesta). During this symposium, new insights are discussed on the biology, origins, pathology and phylogeny of the pathogens; as well as the biological, chemical and genetic management of the diseases that they cause.
The neotropical, jungle understory tree, Theobroma cacao, is the source of chocolate. Linnaeus' name for the genus (theos [God] + broma [beverage] = beverage of the Gods) recognizes the Maya's belief in the plant's divine origins (16). The plant's common and species names are a Spanish version of the Nahuatl name, kakau (16). The common name cocoa is a mistaken spelling of cacao; it now refers to the commercial product, not the crop (7).

T. cacao originated in the headwaters of the Amazon River (eastern Ecuador and Peru) $(7,40,57)$. Archeological records indicate that it was domesticated at least 2,600 years ago in Mesoamerica $(7,45)$. Cacao seeds (beans) were used as currency and in a beverage the Aztecs called xocoatl. The Aztec name was corrupted to chocolatl by the Spaniards and was the precursor of the word chocolate (16). The solid, sweetened product that is known today as chocolate was first made in Europe in the early 1800s.

T. cacao is a member of a large family, the Malvaceae, which is comprised of the former families Sterculiaceae (cacao and kola), Bombacaeae (baobab, durian, and kapok), Malvaceae sensu lato (cotton, hibiscus, and okra), and Tiliaceae (basswood) (36). Recent phylogenetic analyses indicate that the current, more broadly defined Malvaceae is monophyletic (36).

Corresponding author: R. C. Ploetz; E-mail address: kelly12@ufl.edu

* The $\boldsymbol{e}$-Xtra logo stands for "electronic extra" and indicates that the online version contains supplemental material not included in the print edition. Figures 2 and 3 appear in color online.

doi:10.1094/PHYTO-97-12-1634

(C) 2007 The American Phytopathological Society
Cacao is one of the most important tropical crops (23). Almost 4 million metric tons (MMT) of beans were produced in 2005, and the 2.7 MMT that were traded internationally in 2003 were worth $\$ 4.2$ billion. In 2001, the global chocolate market was worth $\$ 73$ billion.

Although the crop began to be disseminated globally shortly after European contact, virtually all production remained in the Western Hemisphere well into the 19th century (Fig. 1). By 1900, $20 \%$ of all beans came from outside the Americas (10), and by the turn of the 21 st century, the west had become a relatively minor producer. In $2005,86 \%$ of the total came from the Eastern Hemisphere, $78 \%$ of which originated in only four countries (23) (Table 1). Principle reasons for this change in the primary centers of cacao production were damaging diseases in the Americas that do not occur in Africa and Asia.

This review and papers that follow are from a symposium on cacao diseases that was held at the joint APS/CPS/MSA meeting in Québec City in $2006(1,17,22,27,28,31,53,63)$. In this brief summary, this topic is introduced and three important diseases that could not be covered during the symposium are discussed.

\section{PRODUCTION CONSTRAINTS}

Diverse factors impact cacao production worldwide. Among the biotic constraints are mirids (Heteroptera: Miridae), which cause estimated annual losses between 100,000 and 200,000 MMT. The species involved include Sahlbergella spp., Distantiella theobroma, and Helopeltis spp. in West Africa, and Monalonian spp. in Latin America. The cocoa pod borer, Conopomorpha cramerella, 
causes annual losses of 40,000 tons in Asia. Mammals and birds cause significant, but mainly local, problems $(3,9,19,69)$. Indirect losses result from mealybugs, which vector the Cacao swollen shoot virus (CSSV), and a Xyleborus beetle that vectors Ceratocystis cacaofunesta, cause of Ceratocystis wilt.

Although they are important, pests cause less damage to cacao than do diseases. Purdy et al. (60) listed several dozen cacao diseases, most of which are caused by fungi. Less common pathogens include alga, bacteria, nematodes, parasitic plants, stramenopiles, and viruses. The top five diseases reduce production by about $20 \%$ annually (ca. 800,000 tons or 3/4 billion dollars) (9) (Table 2). Diseases would be even more destructive if the most damaging had wider distributions.

The major diseases of cacao are listed in Table 2 in descending order of the losses they cause $(3,9,22)$. Among the most potentially damaging diseases are those caused by closely related hemibiotrophic basidiomycetes (2). Frosty pod, caused by Moniliophthora rorei, is most worrisome (53). Although it is currently responsible for less damage than the leading diseases, this is due to its absence in the major producing countries. In Peru, where it occurs alongside black pod and witches' broom (number one and two diseases in Table 2), frosty pod is most prevalent, severe, and serious in terms of yield losses $(21,53)$.

After frosty pod, witches' broom, caused by M. perniciosa (previously Crinipellis perniciosa), may pose the second greatest threat worldwide (Fig. 2) (21,22). It also has a narrow geographic range, and is found in only three of the top 10 producing countries (Tables 1 and 2). Witches' broom can cause significant losses (21). It decimated production in Brazil, first in Rôndonia in the 1970s (50\% pod losses within 6 years), then in Bahia in the early 1990s (60\% reduction in 5 years). Elsewhere in South America and the Caribbean, losses are reported to range from 30 to $90 \%$. Brazil, the world's number one and two producer for much of the 20th century, now ranks a distant 5th due mainly to the impact of witches' broom (23).

The introduction of frosty pod and witches' broom to West Africa would be disastrous (21). About $70 \%$ of the world's production of cacao occurs in this region (2.7 MMT in 2005). Production there relies largely on susceptible Amelonado genotypes. Environmental conditions throughout the cacao-producing areas would appear to be conducive to the rapid spread of both diseases. Losses of upwards of 1 MMT could be expected if either disease crossed the Atlan-

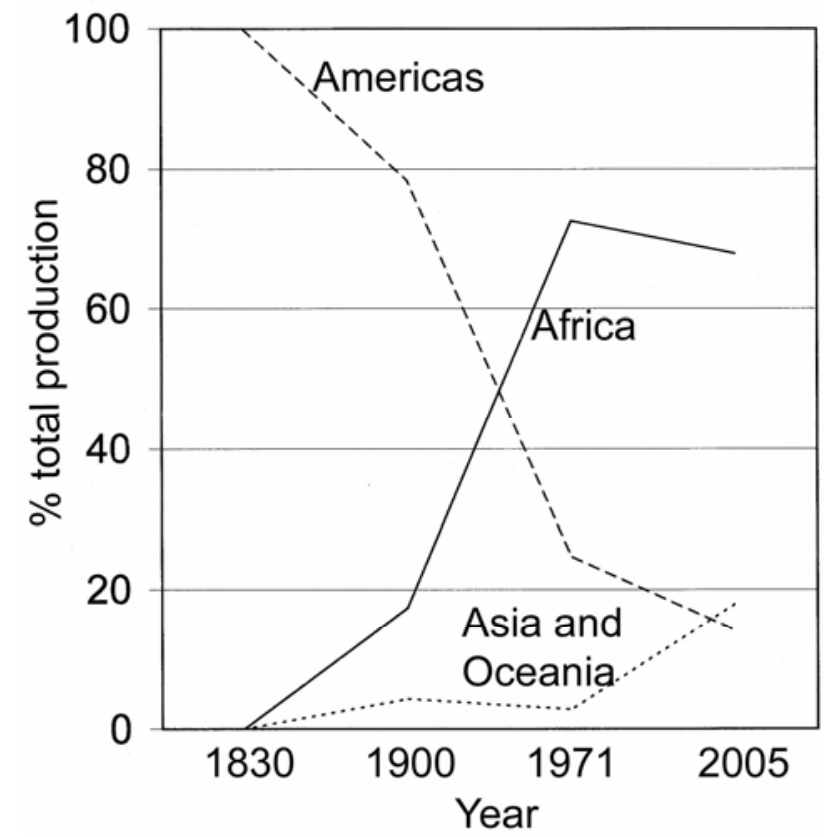

Fig. 1. Regional trends in global cacao production since 1830. Data are from references $(10,23,40)$. tic, and smallholders who produce most of the crop in West Africa ( $80 \%$ of the farms are $<3$ ha in size) would be severely impacted.

Most of the remaining diseases in Table 2 also have narrow distributions. Black pod occurs throughout the tropics, but the most damaging agent, Phytophthora megakarya, is found only in West Africa $(20,22,27)$. Two other new encounter pathogens, CSSV and Oncobasidium theobromae, as well as one that may have coevolved with cacao, Ceratocystis cacaofunesta, also have limited ranges $(5,18,41)$.

Safe movement of cacao germplasm. The safe movement of pathogen-free germplasm is a high priority of cacao improvement programs, and criteria have been established to facilitate this goal (25). Seed are preferred when disseminating germplasm because few cacao pathogens are internally or externally carried with seed. When seed are not available or desired (because cacao is an outcrossed plant, seedlings are usually hybrids), virus-indexed in vitro material is preferred (25). Failing this, budwood can be used. However, it should be treated to eliminate insects and mites, and should be maintained in quarantine to confirm that it is not infected with viruses $(11,12,14,39,49)$ or systemic fungi, such as O. theobromae $(28,37)$.

In the following papers, the status and management of most of the diseases in Table 2 are reviewed $(1,17,22,27,28,31,53,63)$. In the present paper, three diseases that were not covered in the symposium are discussed: cacao swollen shoot, cushion gall and black root rot.

Cacao swollen shoot. Cacao swollen shoot is restricted to the Eastern Hemisphere (a report from Trinidad has not been confirmed) (41). It was first described in 1936 in present-day Ghana where 200 million cacao trees have been destroyed in attempts to manage the disease (41). The disease is also found in Benin, Côte d'Ivoire, Indonesia (Sumatra), Liberia, Malaysia (Sabah), Nigeria, Papua New Guinea, Sierra Leone, Sri Lanka, and Togo $(13,41)$. Losses in 2001 were estimated at 50,000 MMT (9).

CSSV, a member of the genus Badnavirus, causes this disease (41). CSSV is genetically variable and different strains cause an array of symptoms depending on host genotype $(25,41)$. Symptoms include all or some of the following: leaf and pod chlorosis; transient red leaf veins and mottling; root atrophy and stunting; and root and stem swelling. Highly pathogenic strains cause severe leaf chlorosis and result in rapid deterioration and death of cacao (14).

CSSV particles are bacilliform and measure 121 to $130 \times$ $28 \mathrm{~nm}$. CSSV has a circular double-stranded DNA genome, which is ca. $7 \mathrm{~kb}$. The genome has five putative open reading frames (47). Maximum DNA sequence variability among the six strains of CSSV that have been analyzed to date is $29.4 \%$, which is comparable to variability known for two other badnaviruses, Banana streak virus and Sugarcane bacilliform virus. Sequence variation in CSSV complicates its detection.

TABLE 1 . The 10 most important producers of cacao in $2005^{\mathrm{a}}$

\begin{tabular}{lcr}
\hline Country & $\begin{array}{c}\text { Production } \\
(\mathrm{MT})\end{array}$ & \% Total \\
\hline Ivory Coast & $1,330,000$ & 33.9 \\
Ghana & 736,000 & 18.8 \\
Indonesia & 610,000 & 15.5 \\
Nigeria & 366,000 & 9.3 \\
Brazil & 214,774 & 5.5 \\
Cameroon & 180,000 & 4.6 \\
Ecuador & 137,178 & 3.5 \\
Colombia & 55,298 & 1.4 \\
Mexico & 48,405 & 1.2 \\
Papua New Guinea & 42,500 & Other: 5.2 \\
World total: & $3,923,183$ & Asia and Oceania: 18.08 \\
& & Western Hemisphere: 14.06 \\
\hline
\end{tabular}

a Figures are in metric tons (23). 
CSSV is moved in vegetative materials (it can latently infect cuttings that are used for clonal propagation for up to 20 months), and is vectored by at least 14 species of mealybugs (Homoptera: Coccidae) in the genera Planococcus, Planococcoides, Pseudococcus, Dysmicoccus, and Ferrisia (25). The virus is not saptransmissible in cacao, nor is it seed-transmitted. About 40 species in the Malvaceae are infected and develop symptoms, whereas 150 species in 28 other families are not susceptible (14). Several of the affected species are indigenous West African plants, including baobab, kapok, and Cola spp.

Although CSSV is apparently a new-encounter pathogen of cacao, its origin is not clear. Because the original reports were from West Africa and several relatives of cacao are alternative hosts in this region, it is generally accepted that infection in these species antedated that in cacao in West Africa (14). However, Tinsley (68) and Lockhart and Sachey (41) argued that the evidence for this assumption is equivocal. The only species that is commonly infected by CSSV in nature, Cola chlamydantha, is found only in Western Ghana. Based on historical evidence and infectivity assays, Bald and Tinsley (6) suggested that C. chlamydantha was not a primary host but was, in fact, affected by CSSV that came from cacao. The presence of CSSV in Asian countries, in which West African cacao germplasm has not been introduced, also argues against a West African origin for CSSV.

CSSV was not introduced to Africa via cacao, but it is in this crop that the virus is now spread (66). Thus, management of swollen shoot depends upon identifying and eradicating infected cacao plants. Enzyme-linked immunosorbent assay (ELISA) and immunoelectron microscopy (IEM) have been developed for detecting CSSV (62). However, these assays are not reliable for all strains of this serologically heterogeneous virus (41) (at least eight serogroups of CSSV exist [35]). Polymerase chain reaction amplification may provide a more reliable means of identification $(41,46)$. Budwood should be tested for the presence of virus by grafting it to West African Amelonado seedlings, which develop conspicuous symptoms when infected (25).

Before leaving the discussion of this disease, it is important to note that swollen shoot interacts with other diseases. Opoku (48) reported that cacao trees that were affected by CSSV were predisposed to Phytophthora canker in Ghana. A more interesting interaction occurs with the cushion gall disorder. Cushion gall is caused by Albonectria (syns. Calonectria and Nectria) rigidiuscula (anamorph: Fusarium decemcellulare), usually in close association with mirids (54). Thresh (67) and Longworth (42) concluded that swollen shoot did not kill trees in Nigeria unless they were also debilitated by $A$. rigidiuscula and mirids. However, in Ghana death occurred when trees were affected by severe strains of CSSV, even when they were protected from the cushion gall factors (14).

Cushion/green point gall and dieback. Two types of symptoms are associated with $A$. rigidiuscula infection of cacao (i) disorganized meristematic growth on which forms caulinary and

TABLE 2. The major diseases of cacao, Theobromae cacao

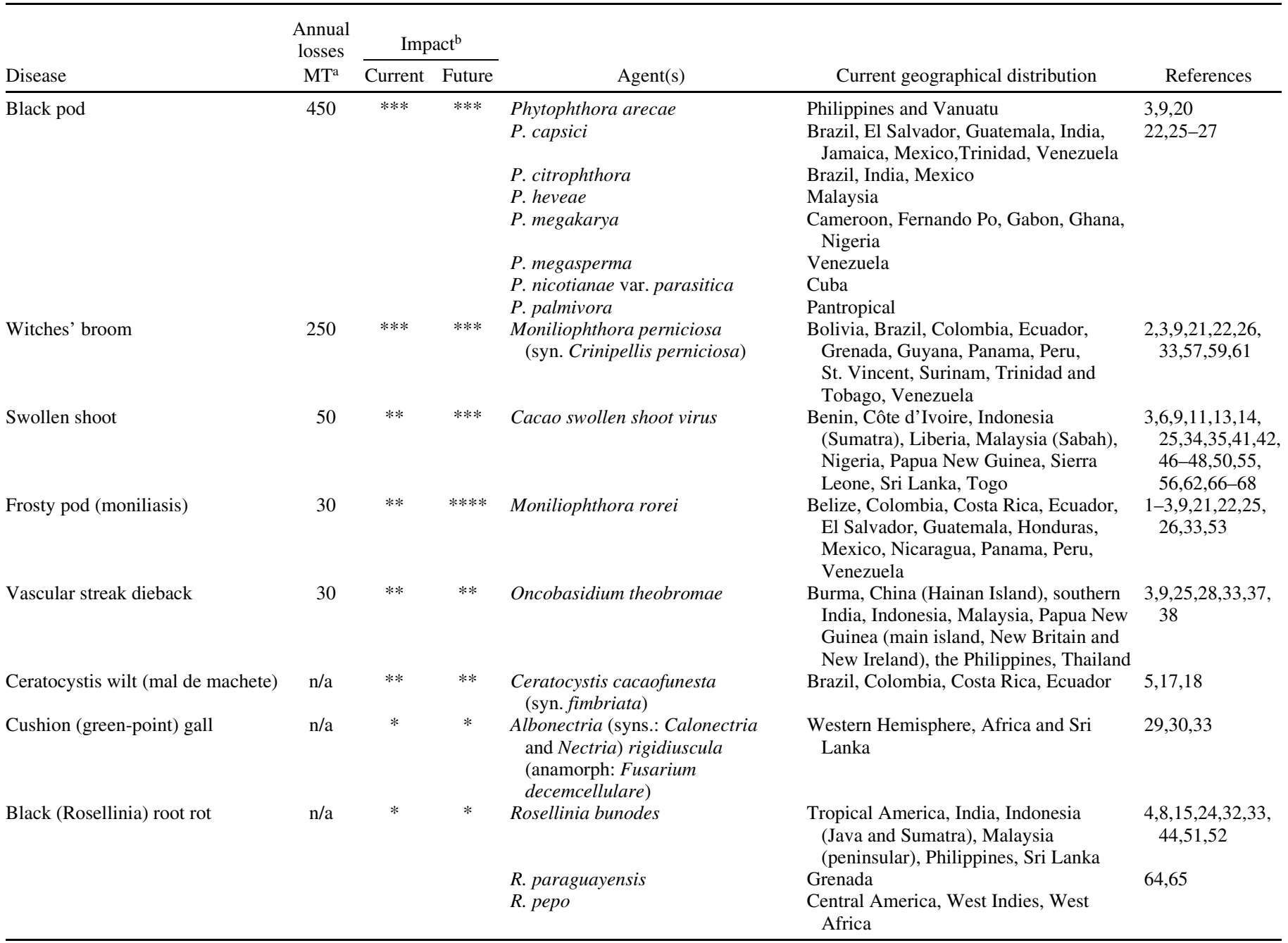

${ }^{a}$ Diseases are listed in order of current loss estimates; figures are in 1,000s of metric tons (MT) or are not available (n/a) $(3,9)$.

${ }^{\mathrm{b}}$ Relative impact is as follows: $*=$ low; $* *=$ moderate; $* * *=$ high; $* * * *=$ very high. Future impact is based on the potential destruction a given disease would cause if it were disseminated outside its current geographic range. 
vegetative primordia (= cushion galls or green point galls), and (ii) dieback $(29,30,33,54)$. These symptoms are discussed due to their impact and the fact that they can be confused with those of witches' broom (58). Another symptom that is associated with this pathogen on cacao, descending tracheomycosis (43), is not discussed.

Holliday (33) reviewed pre-1970 publications; little of note has been published since. First reported in British Guiana in 1905, this disease became prevalent in both hemispheres in the 1950s, prompting the bulk of the published research that is currently available. Today, the gall symptom is widely distributed in the Western Hemisphere and West African production areas.

Flower cushions are affected most often, but galls also develop at leaf nodes and at wounded areas on main branches or trunks (29). Cushion galls usually produce no flowers or a few that do not set pods (58). Galls are hemispherical, may be quite large (Hansen [29] reported a 48-cm-diameter, 3-kg gall in Costa Rica), and are comprised of many small buds (green points) most of which may be lost as the gall ages (Fig. 3). Seedlings are most susceptible and develop symptoms within 2 weeks of inoculation (33). Symptom development on flower cushions and pod stalks was more variable often taking up to 5 months. The identity of the same pathosystem in Africa and the Americas was confirmed when strains of $A$. rigidiuscula from both hemispheres were shown to cause galls and to be sexually compatible (29).

Dieback, wherein stagheads of debilitated branches develop, is also caused by $A$. rigidiuscula. This situation can be complex (33). In West Africa it is initiated by pathogens or insects, including $A$. rigidiuscula, mirids, CSSV, Diplodia theobromae and Phytophthora palmivora. Mirids, yield deterrents in their own right, facilitate infection by $A$. rigidiuscula and are important factors in disease development (33).

Management of these diseases includes the removal and burning of symptomatic trees. Although cushion gall and dieback symptoms can be confused with those caused by witches' broom, they differ in several ways. Pod distortion and basidiocarps of M. perniciosa only develop on trees with witches' broom. In addition, terminal distortions that resemble symptoms of witches' broom can develop in volunteer seedlings with dieback, but not in mature tree shoot terminals and leaf axils of trees (58).
Black (Rosellinia) root rot. Black root rot (also known as Rosellinia root rot) of cacao was first reported in 1893 in Latin America and the Caribbean (65). The disease's common name refers to black hyphae that are produced on affected cacao roots.

Over $50 \%$ of the farms in some cacao-growing areas of Colombia have been affected by this disease and, 7 years after planting, less than half of the original trees in these areas survived $(4,15)$. Black root rot killed up to $20 \%$ of the 3 -year-old trees in the BiguáPeruibe region in Brazil (24), and between 1997 and 2001, 45 clones in the germplasm collection of the Centro Agronomico Tropical de Investagación y Enseñanza (CATIE) in Costa Rica were lost due to a combination of this disease and Ceratocystis wilt (44).

The genus Rosellinia is a geographically and morphologically diverse assemblage of fungi. Petrini (51) recognized three categories of species: strict saprophytes (nonpathogens), endophytes that are occasionally pathogenic, and severe root pathogens. Three in the later group are significant problems on cacao, Rosellinia bunodes, $R$. pepo, and $R$. paraguayensis. Each of these species falls in the D4 cluster of Petrini and Petrini (52); it contains tropical taxa with Dematophora anamorphs.

$R$. bunodes, $R$. pepo, and $R$. paraguayensis affect many important tropical crops, such as banana, coffee, tea, citrus, rubber, avocado, and timber species $(8,64)$. Black root rot is less aggressive than another serious root disease of cacao, Ceratocystis wilt, but often interacts with it and other factors. Despite Petrini's (51) characterization of $R$. bunodes, $R$. pepo, and $R$. paraguayensis as severe root pathogens, they are less important than other cacao pathogens in Table 2 .

Black root rot is particularly important in acidic soils with high organic matter content. Because the responsible species have wide host ranges and persist in colonized organic debris, black root rot can be difficult to manage $(33,65)$. Adopted in various management schemes have been: sanitation (removal of infected debris); soil treatment with fungicides, fumigants or solarization; and biological control (44).

\section{CONCLUSIONS}

T. cacao has a long history as a significant crop in the neotropics $(7,45)$. Its more recent importance in West Africa and Asia
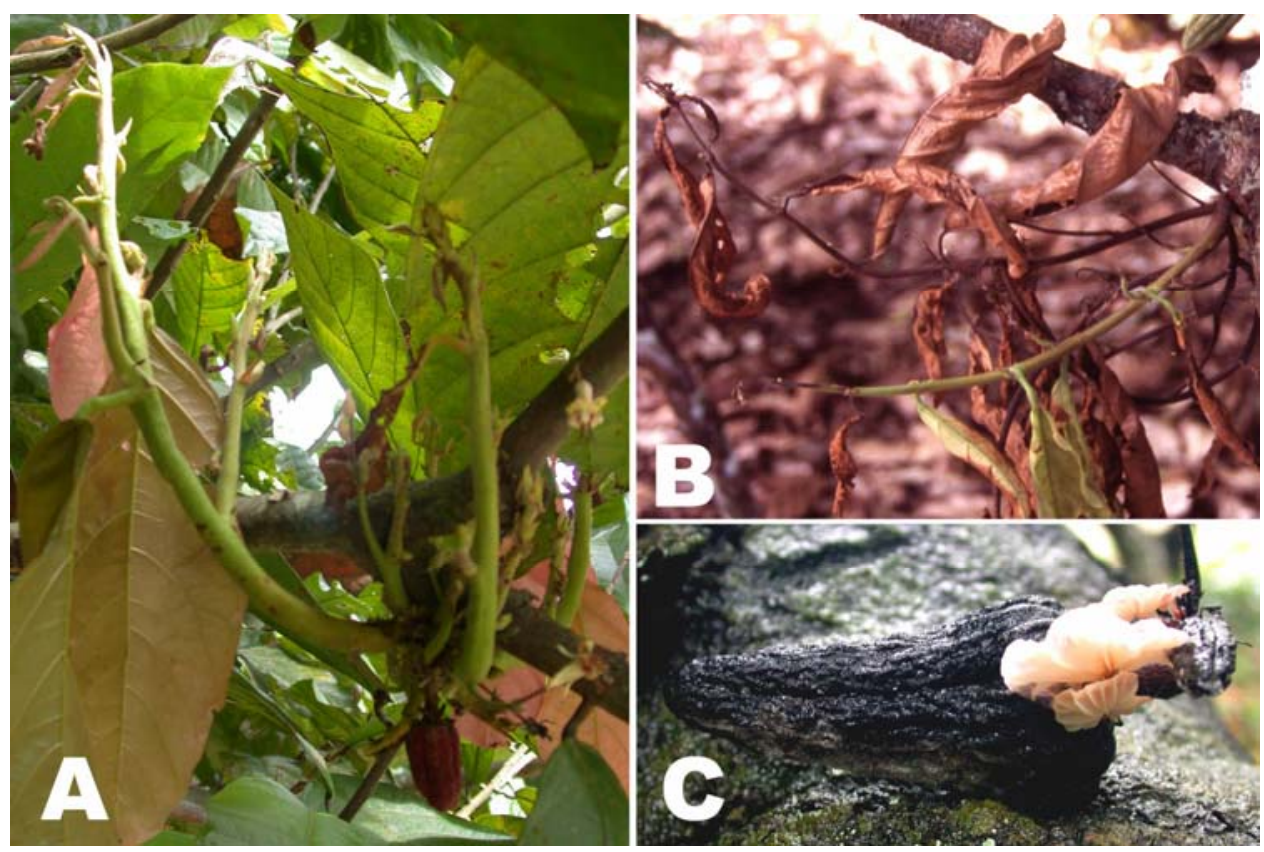

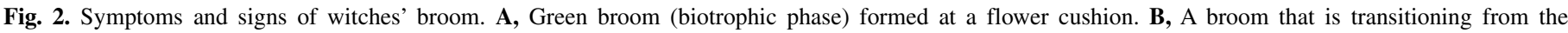

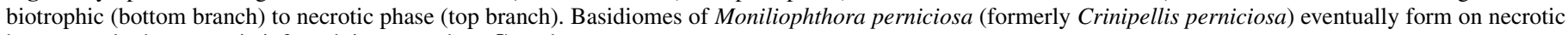
brooms and other necrotic infected tissues such as $\mathbf{C}$, pods. 


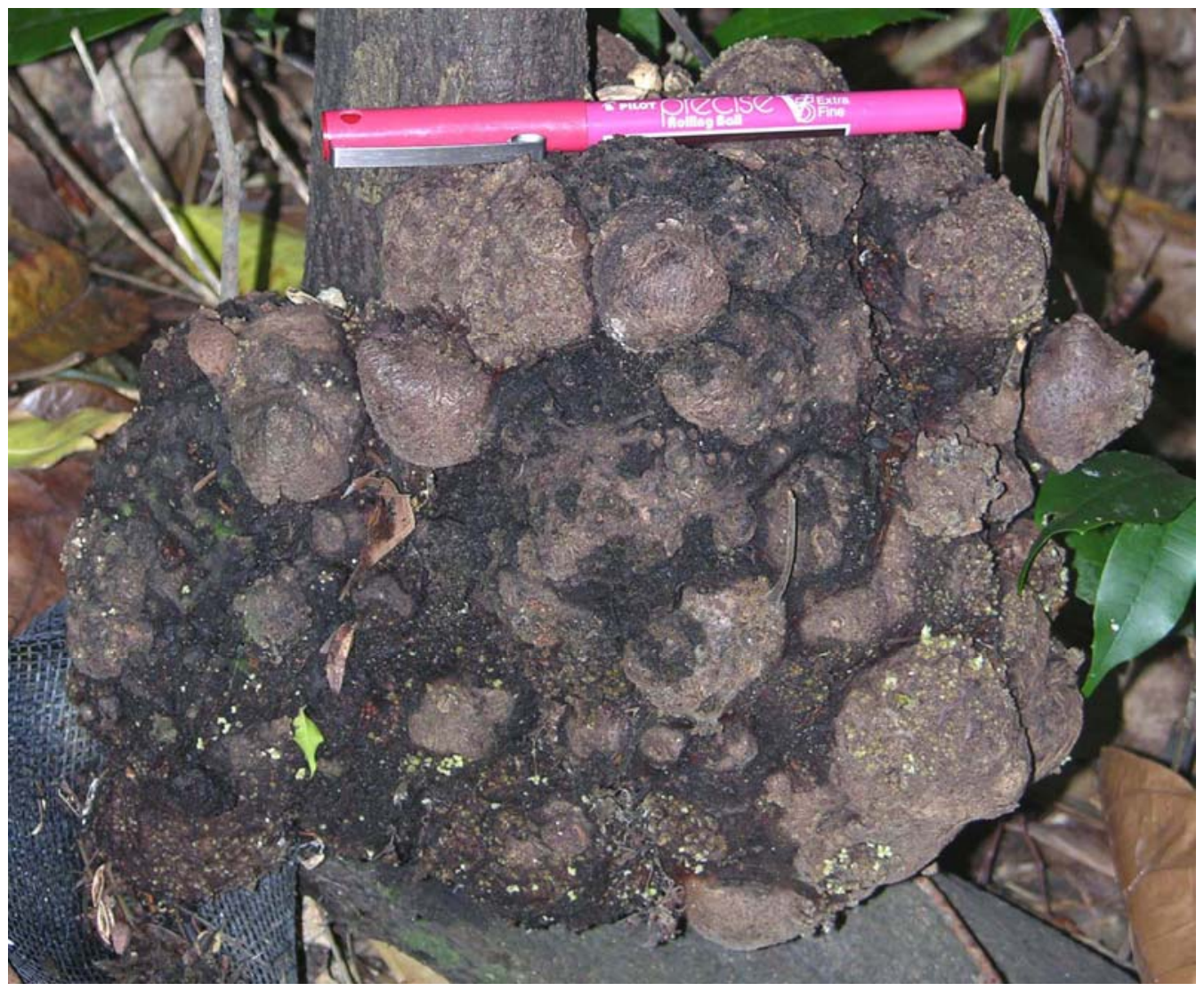

Fig. 3. A large green point gall, caused by Albonectria rigidiuscula, that has formed at the base of a cacao accession at the USDA-ARS Subtropical Horticultural Research Station in Miami, FL.

has been enabled, in large part, by the absence of several American diseases. Very significant losses would occur if these diseases, in particular frosty pod and witches' broom, spread to African and Asian production areas.

In general, the most important pathogens of cacao have restricted geographic distributions. Management of the diseases that they cause will rely on effective quarantines to limit the distributions of exotic pathogens (25). Where these diseases are found, cultural measures (mainly sanitation) are most effective, although biological and chemical treatments are also being developed and used (31). Eventually, disease-resistant, high-yielding clones may provide the most effective tool to manage these diseases (63).

\section{ACKNOWLEDGMENTS}

Speakers and participants in the symposium gratefully acknowledge encouragement and monetary support that was provided by Mars, Incorporated.

\section{LITERATURE CITED}

1. Aime, M. C. 2006. New phylogenies: Revelations on cacao pathogens and the diseases they cause. (Abstr.) Phytopathology 96(suppl.):S138.

2. Aime, M. C., and Phillips-Mora, W. 2005. The causal agents of witches' broom and frost pod rot of cacao (chocolate, Theobromae cacao) form a new lineage of Marasmiaceae. Mycologia 97:1012-1022.

3. Anonymous. The World's Worst Cocoa Problems. Online at http:// www.dropdata.net/cocoa/cocoa_prob.htm.

4. Aranzazu, H. F., Cárdenas, L. J., Mujica, J. J., and Gómez, Q. R. 1999. Manejo de las llagas radicales (Rosellinia sp.). In: Boletin de Sanidad Vegetal 23, Instituto Colombiano Agropecuario (ICA) and Corpoica, Santafè de Bogotá, Colombia, p. 35.

5. Baker, C. J., Harrington, T. C., Krauss, U., and Alfenas, A. C. 2003. Genetic variability and host specialization in the Latin American clade of Ceratocystis fimbriata. Phytopathology 93:1274-1284.

6. Bald, J. G., and Tinsley, T. W. 1970. A quasi-genetic model for plant viruses host ranges. IV. Cacao swollen shoot and mottle leaf viruses. Virology 40:369-378.
7. Bartley, B. G. D. 2005. The Genetic Diversity of Cacao and its Utilization. CABI Publishing. Wallingford, UK.

8. Booth, C. and Holliday, P. 1972. Rosellinia pepo. In: Descriptions of Pathogenic Fungi and Bacteria, vol. 354. Commonwealth Mycological Institute, Kew, Surrey, UK.

9. Bowers, J. H., Bailey, B. A., Hebbar, P. K., Sanogo, S., and Lumsden, R. D. 2001. The impact of plant diseases on world chocolate production. Published online. Plant Health Prog. doi:10.1094/PHP-2001-0709-01-RV.

10. Bradeau, J. 1969. Le Cacaoyer. Paris, Maisonneuve et Larose.

11. Brunt, A. A. 1970. Cacao swollen shoot virus. No. 10 in: CMI/AAB Descriptions of Plant Viruses. Commonwealth Mycological Institute, Kew.

12. Brunt, A. A. 1970. Cocoa yellow mosaic virus. No. 11 in: CMI/AAB Descriptions of Plant Viruses. Commonwealth Mycological Institute, Kew.

13. Brunt, A., Crabtree, K., Dallwitz, M., Gibbs, A., and Watson, L. (eds.). 1996. Viruses of Plants. Descriptions and Lists from the VIDE Database. CAB International, Wallingford, UK.

14. Brunt, A. K., and Kenton, R. H. 1971. Viruses infecting cacao. Rev. Plant Pathol. 50:591-602.

15. Cadavid, S. 1995. Rosellinia in cocoa. Cocoa Growers' Bull. 49:52-59.

16. Dillinger, D. L., Barriga, B., Escárcega, S., Jimenez, M., Salazar Lowe, D., and Grivetti, L. E. 2000. Food of the Gods: Cure for humanity? A cultural history of the medicinal and ritual use of chocolate J. Nutr. 130:2057S-2072S

17. Engelbrecht, C. J., Harrington, T. C., and Alfenas, A. 2007. Ceratocystis wilt of cacao-A disease of increasing importance. Phytopathology 97: 1648-1649.

18. Engelbrecht, C. J. B., and Harrington, T. C. 2005. Intersterility, morphology and taxonomy of Ceratocystis fimbriata from sweet potato, cacao and sycamore. Mycologia 97:57-69.

19. Entwistle, P. F. 1972. Pests of Cocoa. Longman, London.

20. Erwin, D. C., and Ribiero, O. K. 1996. Phytophthora Diseases Worldwide. American Phytopathological Society, St. Paul, MN.

21. Evans, H. C. 2002. Invasive Neotropical Pathogens of Tree Crops. Pages 83-112 in: Tropical Mycology: Volume 2, Micromycetes. R. Watling, J. Frankland, M. Ainsworth, S. Isaac, and C. Robinson, eds. CABI Publishing, Wallingford, UK.

22. Evans, H. C. 2007. Cacao diseases-The trilogy revisited. Phytopathology $97: 1640-1643$. 
23. FAOSTAT online database. 2006. http://faostat.fao.org/

24. Feitosa, M. I. and Pimentel, C. P. V. 1991. Rosellinia bunodes Berk. Et Br. Sacc. pathogenic fungus to cacao Theobroma cacao L. in the state of São Paulo. Cientifica (Jaboticabal) 19:31-35

25. Frison, E. A., Diekmann, M., and Nowell, D. (eds.) 1999. FAO/IPGRI Technical Guidelines for the Safe Movement of Germplasm. No. 20. Cacao (1st revision). Food and Agriculture Organization of the United Nations, Rome/International Plant Genetic Resources Institute, Rome.

26. Fulton, R. H. 1989. The cacao disease trilogy: Black pod, Monilia pod pot, and witches'-broom. Plant Dis. 73:601-603.

27. Guest, D. 2007. Black pod: Diverse pathogens with a global impact on cocoa yield. Phytopathology 97:1650-1653.

28. Guest, D., and Keane, P. 2007. Vascular-streak dieback: A new encounter disease of cacao in Papua New Guinea and Southeast Asia caused by the obligate basidiomycete Oncobasidium theobromae. Phytopathology 97: 1654-1657.

29. Hansen, A. J. 1963. The role of Fusarium decemcellulare and Fusarium roseum in the greenpoint cushion gall complex of cacao. Turrialba 13:8087.

30. Hansen, A. J. 1966. Fusaria as agents of cacao green point cushion gall in the Caribbean and in Latin America. Plant Dis. Rep. 50:229-233.

31. Hebbar, P. K. 2007. Cacao diseases: A global perspective from an industry point of view. Phytopathology 97:1658-1663.

32. Hernandez, F. A. 1996. Behavior of the root rot Rosellinia pepo Pat. on roots of the cocoa tree. Fitopatol. Colombiana 20:7-10.

33. Holliday, P. 1980. Fungus Diseases of Tropical Crops. Cambridge University Press, Cambridge.

34. Hughes, J. d'A., and Ollennu, L. L. A. 1993. The virobacterial agglutination test as a rapid means of detecting cocoa swollen shoot virus. Ann. Appl. Biol.122:299-310.

35. Hughes, J. d'A., Adomako, D., and Ollennu, L. L. A. 1995. Evidence from the virobacterial agglutination test for the existence of eight serogroups of cocoa swollen shoot virus. Ann. Appl. Biol. 127:297-307.

36. Judd, W. S., Campbell, C. S., Kellogg, E. A., Stevens, P. F., and Donoghue, M. J. 2002. Plant Systematics. A Phylogenetic Approach. 2nd ed. Sinauer Associates, Inc., Sunderland, MA.

37. Keane, P. J., and Prior, C. 1991. Vascular streak dieback of cacao. Phytopathological Papers No. 33. International Mycological Institute, UK.

38. Keane, P. J., Flentje, N. T., and Lamb, K. P. 1972. Investigation of vascular-streak dieback of cocoa in Papua New Guinea. Aust. J. Biol. Sci. 25:553-564.

39. Kenten, R. H. 1977. Cacao necrosis virus. No. 173 in: CMI/AAB Descriptions of Plant Viruses. Commonwealth Mycological Institute, Kew.

40. Lanaud, C., Motomayor, J.-C., and Sounigo, O. 2003. Pages 125-156 in: Genetic Diversity of Cultivated Tropical Crops. P. Hamon, M. Seguin, X. Perrier, and J. C. Glaszmann, eds. CIRAD, SPI, Enfield, NH.

41. Lockhart, B. E. and Sachey, S. T. 2001. Cacao swollen shoot. Pages 172173 in: Encyclopedia of Plant Pathology. O. C. Maloy and T. D. Murray, eds. John Wiley \& Sons, Inc., New York.

42. Longworth, J. F. 1963. The effect of swollen-shoot disease on mature cocoa in Nigeria. Trop. Agric. (Trinidad) 40:275-283.

43. Mariau, D. (ed.) 2001. Diseases of Tropical Tree Crops. Science Publishers, Inc., Enfield, NH.

44. Mendoza García, R. A., Martijn ten Hoopen, G., Kass, D. C. J., Sànchez Garita, V. A., and Krauss, U. 2003. Evaluation of mycoparasites as biocontrol agents of Rosellinia root rot in cocoa. Biol. Control 27:210-227.

45. Motomayor, J.-C., Risterucci, A. M., Lopez, P. A., Ortiz, C. F., Moreno, A., and Lanaud, C. 2002. Cacao domestication I: The origin of the cacao cultivated by the Mayas. Heredity 89:380-386.

46. Muller, E., Jacquet, E., and Yot, P. 2001. Early detection of cacao swollen shoot virus using polymerase chain reaction. J. Virol. Methods 93:15-22.

47. Muller, E., and Sackey, S. 2005. Molecular variability analysis of five new complete cacao swollen shoot virus genomic sequences. Arch. Virol. 150:53-66.

48. Opoku, I. Y., Dakwa, J. T., and Ollennu, L. A. A. 2005. The development of Phytophthora canker on different cocoa genotypes infected with cocoa swollen shoot virus. Trop. Sci. 45:50-53.

49. Owusu, G. K. 1971. Cocoa necrosis virus in Ghana. Trop. Agric. (Trinidad) 48:133-139.

50. Peiris, J. W. L. 1953. Virus diseases of cacao in Ceylon. Trop. Agric. 109:135.

51. Petrini, L. E. 1993. Rosellinia species of the temperate zones. Sydowia 44:169-281.

52. Petrini, L. E., and Petrini, O. 2005. Morphological studies in Rosellinia (Xylariaceae): The first step towards a polyphasic taxonomy. Mycol. Res. 109:569-580.

53. Phillips-Mora, W., and Wilkinson, M. J. 2007. Frosty pod of cacao: A disease with a limited geographic range but unlimited potential for damage. Phytopathology 97:1644-1647.

54. Ploetz, R. C. 2006. Fusarium-induced diseases of tropical, perennial crops. Phytopathology 96:648-652.

55. Posnette, A. P. 1940. Transmission of swollen shoot disease of cacao. Trop. Agric. (Trinidad) 17:98.

56. Posnette, A. P. 1947. Virus diseases of cacao in West Africa. 1. Cocoa viruses 1A, 1B, 1C, and 1D. Ann. Appl. Biol. 34:388-402.

57. Pound, F. J. 1938. Cacao and the witchbroom disease (Marasmius perniciosa) of South America with notes on other species of Theobroma. Yuille's Printery: Port of Spain, Trinidad and Tobago.

58. Purdy, L. H. Fungal diseases of cacao. Online at http://www.cabicommodities.org/Acc/ACCrc/PDFFiles/W-BPD/Ch1.pdf

59. Purdy, L. H., and Schmidt, R. A. 1996. Status of cacao witches' broom: Biology, epidemiology, and management. Annu. Rev. Phytopathol. 34:573-594.

60. Purdy, L. H., Schmidt, R. A., and Gramacho, K. P. 1998. Diseases of Cacao (Theobroma cacao L.). APSnet Online at http://www.apsnet.org/ online/common/names/cacao.asp.

61. Rudgard, S. A., Maddison, A. C., and Andebrhan, T. 1993. Disease management in cocoa, comparative epidemiology of witches' broom. Chapman \& Hall, London and New York.

62. Sagemann, W., Lesemann, D.-E., Paul, H. L., Adomako, D., and Owusu, G. K. 1985. Detection and comparison of some Ghanaian isolates of cacao swollen shoot virus (CSSV) by enzyme-linked immunosorbent assay (ELISA) and immunoelectron microscopy (IEM) using an antiserum to CSSV strain 1A. Phytopathol. Z. 114:79-89.

63. Schnell, R. J., Kuhn, D. N., Brown, J. S., Olano, C. T., Phillips-Mora, W. Amores, F. M., and Motamayor, J. C. 2007. Development of a marker assisted selection program for cacao. Phytopathology 97:1664-1669.

64. Sivanesan, A., and Holliday, P. 1972. Rosellinia bunodes. In: Descriptions of Pathogenic Fungi and Bacteria. vol. 351. Commonwealth Mycological Institute, Kew, Surrey, UK.

65. ten Hoopen, G. M., and Krauss, U. 2006. Biology and control of Rosellinia bunodes, Rosellinia necatrix and Rosellinia pepo: A review. Crop Prot. 25:89-107.

66. Thresh, J. M. 1958. Virus research in Ibadan, Nigeria. Pages 71-73 in: Annual Report 1956-57. West African Cocoa Research Institute, Ibadan, Nigeria.

67. Thresh, J. M. 1960. Capsids as a factor influencing the effect of swollen shoot disease on cacao in Nigeria. Emp. J. Exp. Agric. 28:193-200.

68. Tinsley, T. W. 1971. The ecology of cacao viruses. The role of wild hosts in the incidence of swollen shoot virus in West Africa. J. Appl. Ecol. 8:491-495.

69. Wood, G. A. R., and Lass, R. A. 1985. Cocoa. Longman, London. 